\title{
Agro-techniques for Productive and Profitable Crop Management under Excess Water Regimes
}

\author{
S. K. Dwibedi ${ }^{1 *}$, A. K. Mohanty ${ }^{2}$, N. C. Sarkar ${ }^{3}$ and B. B. Sahoo ${ }^{4}$
}

${ }^{1}$ Dept. of Agronomy, College of Agriculture, Chiplima (OUAT), Sambalpur, Odisha (768 025), India

${ }^{2}$ Dept of Agronomy, PSB (Institute of Agriculture), Visva Bharati, Santiniketan, Birbhum, West Bengal (731 236), India

${ }^{3}$ Horticulture, Regional Research and Technology Transfer Station (OUAT), Semiliguda, Koraput, Odisha (763 002), India

\section{Corresponding Author}

S. K. Dwibedi

e-mail: sanatdwibedi@rediffmail.com

\author{
Article History \\ Article ID: AR1825a \\ Received in $30^{\text {th }}$ June, 2017 \\ Received in revised form $19^{\text {th }}$ September, 2017 \\ Accepted in final form $30^{\text {th }}$ October, 2017
}

\begin{abstract}
Due to climate change, the rainfall pattern has changed dramatically. Vagaries of monsoon and its unpredictable onset or withdrawal or breaks in between become a possible threat for the farmers especially in the rainfed areas. Due to differential rainfall, the rainwater stagnates in the low-lying areas. Like moisture stress or drought, excess moisture or water stagnation for a period of time needs equal attention for successful crop management. Such abiotic stress condition could be managed by two ways; firstly, growing the crops adapted with suitable agro-techniques for potential yield. Secondly, through special cultivation methods that may help to avoid excess moisture. To feed the ever burgeoning population in India due attention is to be paid for increasing the food grain production not only in arable lands but also in areas affected by excess water situations. Varietal substitution of rice with Varshadhan, Hangseswari, Swarna Sub 1 are found befitting due to ecological adaptability. System of rice intensification with more soil organics and early establishment of the rice plants could better sustain submergence under flash flood. Non-traditional crops like water chestnut, fox nut, hogla, sweet flag are very good alternatives to rice in waterlogged areas. Bio-drainage through Casuarina and land alternations through raised and sunken beds could alleviate the problems and diversify the rice-rice cropping system.
\end{abstract}

Keywords: Excess water, agro-techniques, crop management, water logging, bio-drainage

\section{Introduction}

India on an average receives about $119 \mathrm{~cm}$ of rainfall out of which $80-90 \%$ is received during southwest monsoon (June to September) and rest 10-20\% during northeast monsoon (October-December). Due to climate change, the rainfall pattern has changed dramatically. Vagaries of monsoon and its unpredictable onset or withdrawal or breaks in between become a possible threat for the farmers especially in the rainfed areas. Due to differential rainfall, the rainwater stagnates in the low-lying areas. In some areas, the water through seepage and percolation from the reservoirs, dams, rivers and canals flows downward and creates swampy and marshy conditions in the low-lying adjacent command areas or even flood like situation. Natural weather aberrations like tsunami, cyclonic storms and super cyclones often inundate the coastal tracts leading to excess moisture conditions. Like moisture stress or drought, excess moisture or water stagnation for a period of time needs equal attention for successful crop management. Such abiotic stress condition could be managed by two ways; firstly, growing the crops adapted with suitable agro-techniques for potential yield. Secondly, through special cultivation methods that may help to avoid excess moisture.

\section{Crops with Suitable Agro-techniques}

\subsection{Rice (Oryza sativa L.)}

Rice is bread and butter for more than $90 \%$ of South-Asian people, ecologically most diverse crop grown on this Earth. The farmers usually go for direct seeding of paddy in the month of May and June in anticipation of getting a good yield unaffected by the repeated climatologically aberrations. The problem of such rain and/or sea water inundation becomes acute after first week of August and persists till end of October. Thirty or more day's old seedlings are preferred under delayed sowing condition to combat subsequent excess water situations.

Double transplanting is also practiced in some parts of Odisha and Andhra Pradesh in medium/semi deep waterlogged areas local and traditional farmers' varieties of rice like Kadaligoura, Chakaakhi, Barhaghali, Kalapatri, Panidhan, Budhathengua owing to better ecological adaptations are grown in-spite of poor yielding ability.

Cultivars like Varshadhan and Hangseswari from National Rice Research Institute (NRRI), Cuttack are performing better 


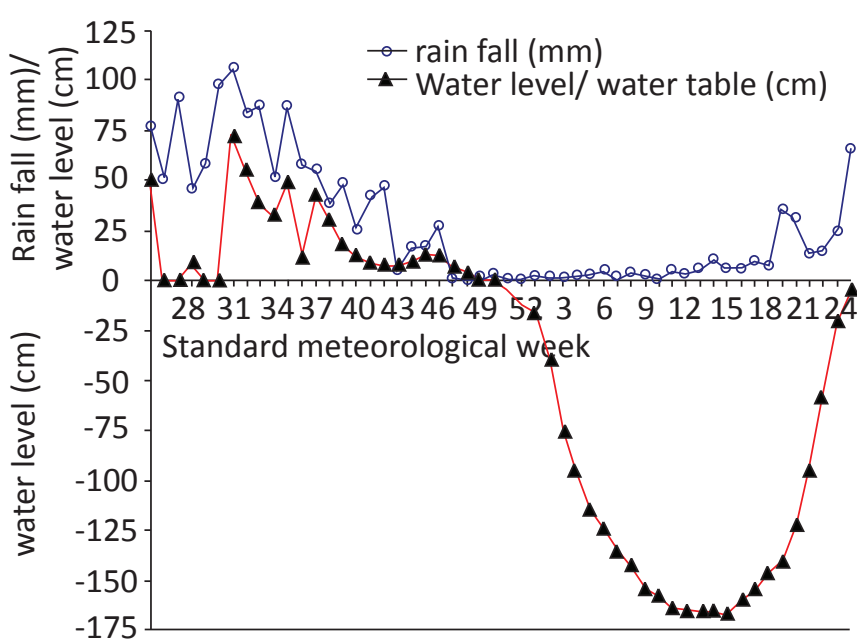

Figure 1: Hydrograph of weekly rainfall and water level of Erasama (Kar et al., 2007)

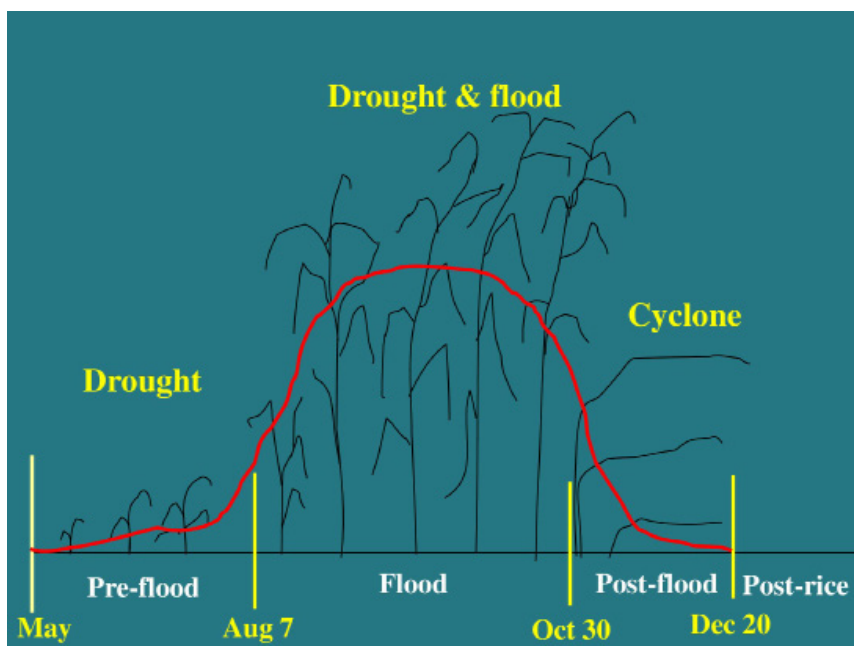

Figure 2: Present scenario of deep water rice ecology (Kar et al., 2007)

than local cultivars under normal and delayed planting The plants grow very well comensurating with the rise in water level (plant height may reach more than $2.0 \mathrm{~m}$ ) and do not fall down even after recession of the excess water at maturity due to stiff and thick culms (plate 1 and 2).

In flash flood affected areas of Uttar Pradesh, Bihar, Punjab, Rajasthan, Assam the flood water completely submerges the crop field during kharif season for a week or two leading to complete failure of agriculture in most cases. Under such situation submergence tolerant rice varieties like Swarna Sub-1, Sarala Sub-1, Durga Sub-1, etc (Plate 3) through genetic engineering, by transferring the submergence tolerant rice gene “FR13A' into the popular rice genotypes.

Water saving rice cultivation popularly known as system of rice intensification (SRI) in flash flood situation has been found to perform better with lesser stand mortality and speedy regeneration of fresh tillers than best management practice (BMP). In Mahanadi flood basins early sowing of rice by $20^{\text {th }}$ June under SRI could overcame the shock of submergence in post vegetative stage, whereas delayed sowings $\left(5^{\text {th }}\right.$ and $20^{\text {th }}$ July) under BMP severely affected the plants and in some cases the entire crop-stand was wiped out (Plate 4, 5 and 6).

\subsection{Water chestnut (Trapha bispinosa)}

Water chestnut popularly known as panisinghara, singharaphal or paniphal. It is one of the neglected crops grown in roadside or railway track side depressions. It is also localized in

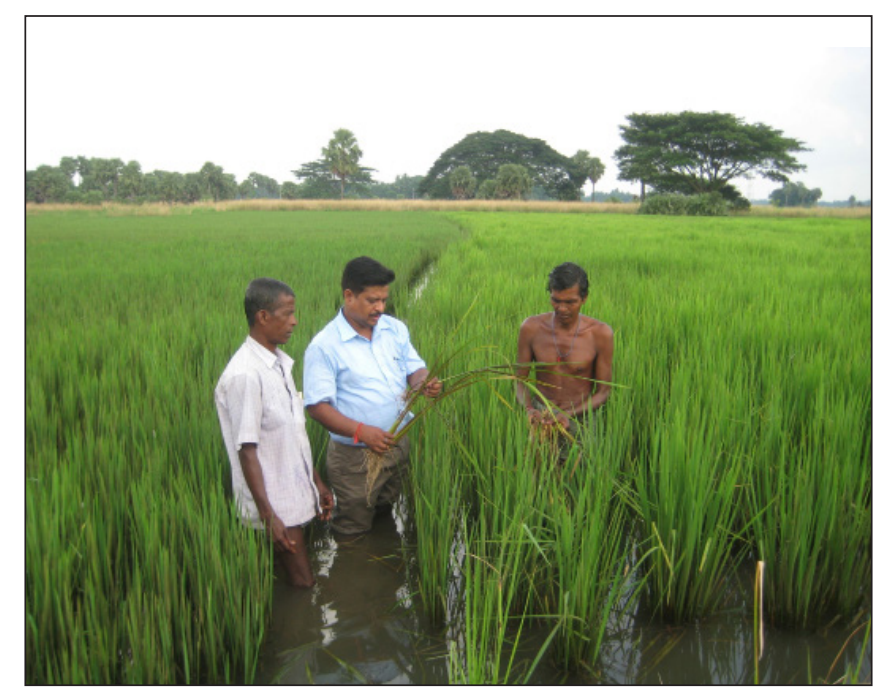

Plate 1: Field visit by KVK Scientist

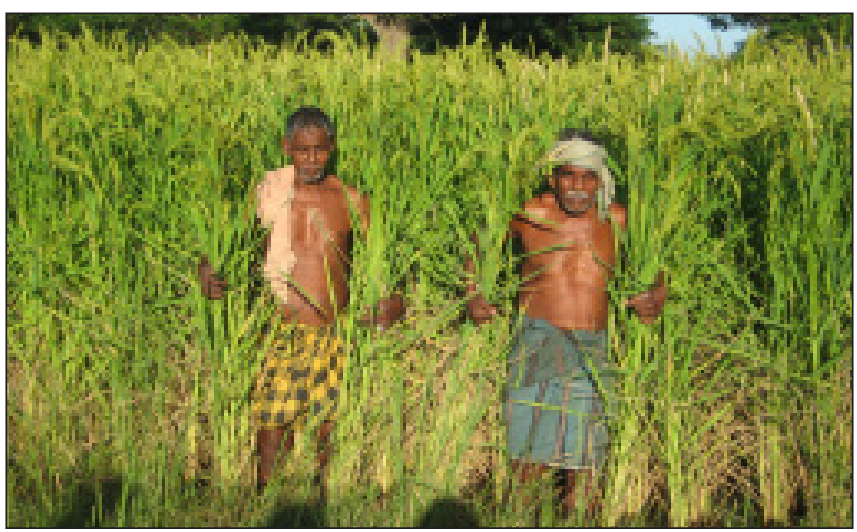

Plate 2: Farmers are happy with cv. Varshadhan

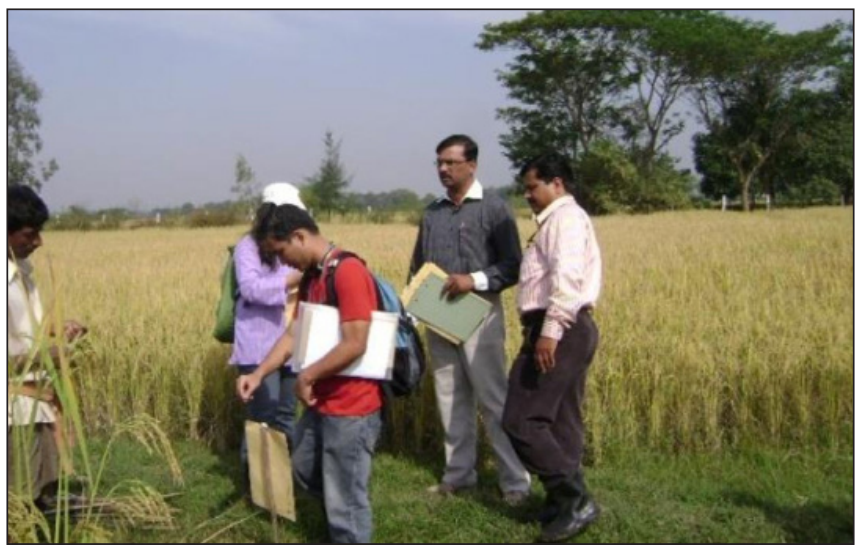

Plate 3: Scientists from IRRI, NRRI and KVK investigating Swarna Sub-1 


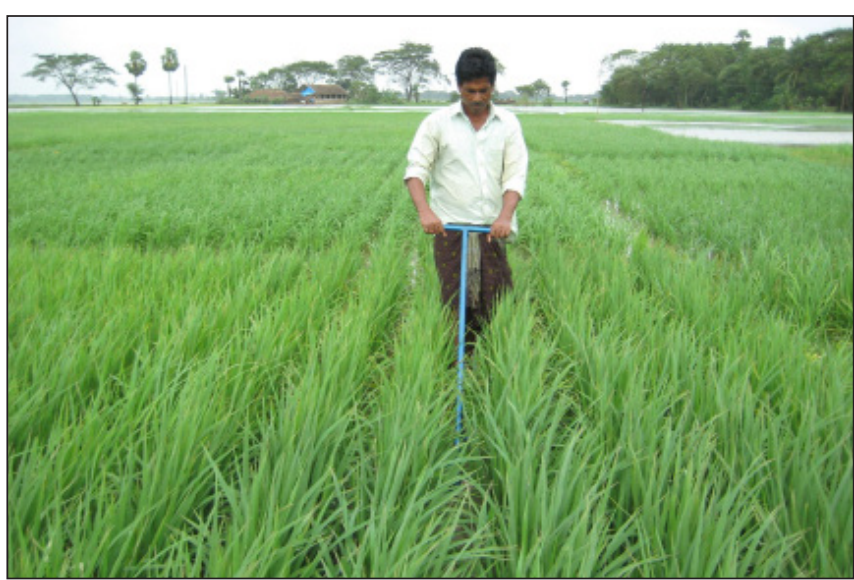

Plate 4: Mr. Nityananda Routray, former Sarpanch in his SRI plots before flood

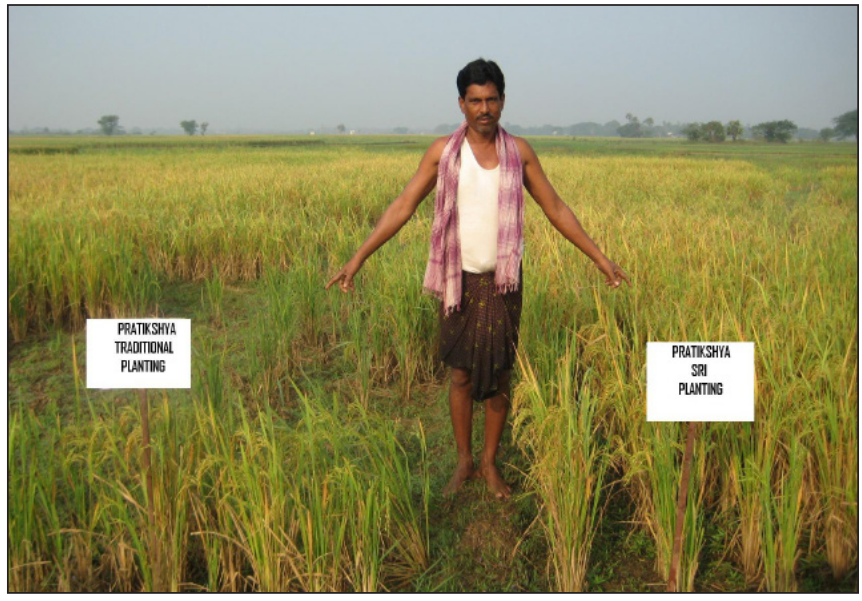

Plate 5: Post-flood comparative view of cv. Pratikshya grown under SRI (his left) and BMP (his right) planted by 30 June

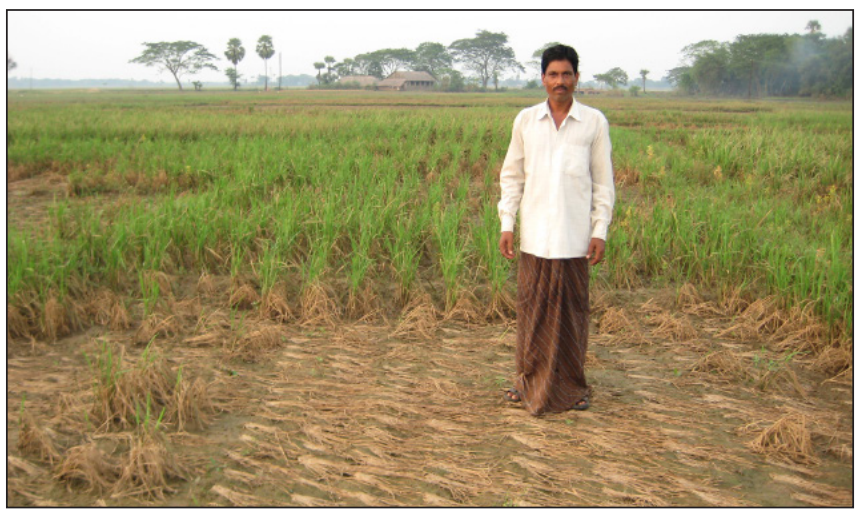

Plate 6. Mr. Routray in rice field planted by 14 August under BMP, completely damaged due to submergence

topographical depressions where water remains stagnant at least up to the month of January. Out of $8.0 \mathrm{~m}$ ha of shallow low land in India, $5.8 \mathrm{mha}$ is in eastern India that provides tremendous scope for its wide scale cultivation. Apart from its fruits used for table purpose as raw or boiled, a significant proportion is processed as flour. Among the available cultivars KNP red, Balasore red, HP red, Balasore green and HP green are widely adopted by the farmers of West Bengal and Odisha. Seedlings are planted in the puddle pond-beds in the month of May to June with FYM of 8-10 tha-1 and $\mathrm{N}: \mathrm{P}_{2} \mathrm{O}_{5}$ and $\mathrm{K}_{2} \mathrm{O}$ @ 40:40:60 kg ha-1. Green genotypes are in general higher yielders than red types. Two weeks old fruits are plucked manually during October to December i.e. 4-6 months after planting with yield of 10-15 $\mathrm{t} \mathrm{ha}^{-1}$. Moreover, with average yield of $10 \mathrm{t} \mathrm{ha}^{-1}$ and market price of Rs. $30 \mathrm{~kg}^{-1}$, a farmer may get net profit of Rs.1,21,000 ha-1 and the water productivity may come to Rs. $33 \mathrm{~m}^{-3}$. It can also be cultivated in farm-ponds integrated with the pisciculture. However, due attention should be taken for maintaining open space either at the periphery or at the centre of the pond for proper aeration of fishes or else they may die of anoxia (Plate 7 and 8). The added advantage with this crop is that it grows with the flood water and there is no fear of crop-failure due to submergence

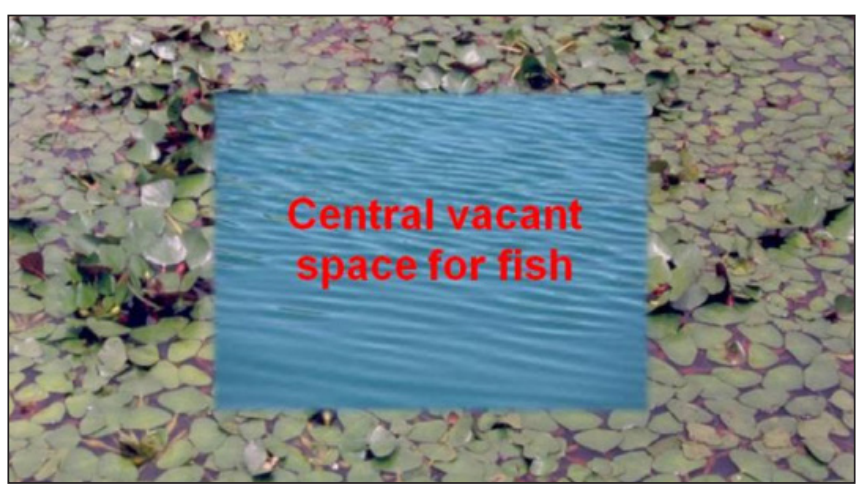

Plate 7: Water chestnut-fish integration with central open space

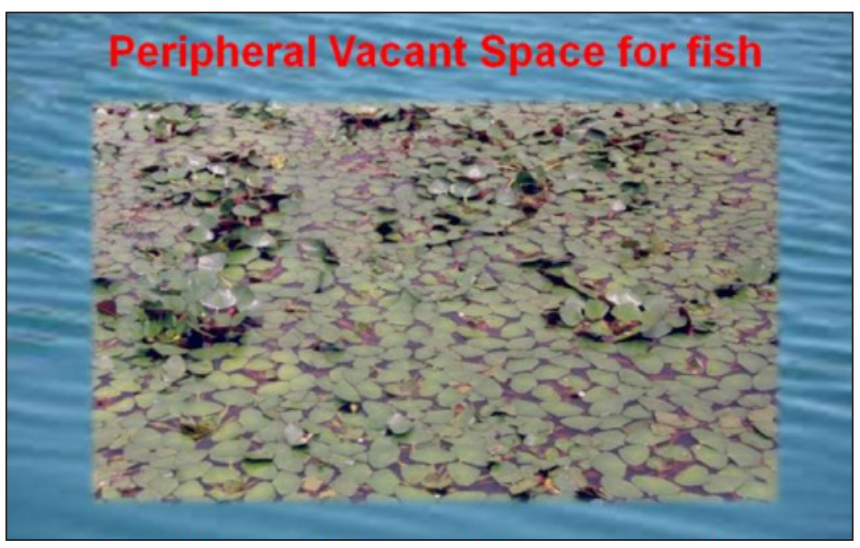

Plate 8: Water chestnut-fish farming with open periphery or lodging.

\subsection{Swamp taro (Colocassia esculenta)}

Swamp taro locally known as panisaro, panikacho, kacholati and lati. It is widely cultivated in Assam, West Bengal and some parts of northeastern Odisha for stolon or runners (Plate 9 and 10). Depending on the varieties, the entire plant or parts like leaves, petioles, runners or stolon are consumed in these areas. There is also a great scope for cultivating this crop in 1.2 $\mathrm{m}$ ha of marshy/ waterlogged areas in this country. 


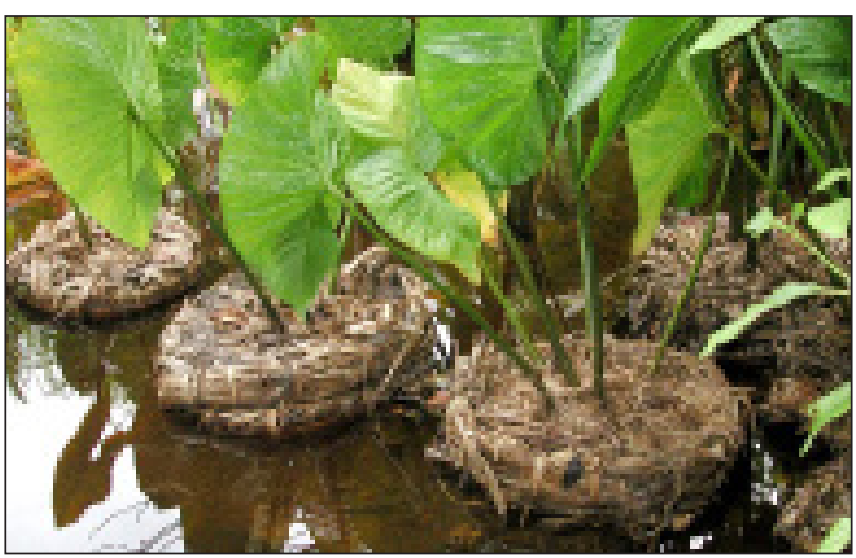

Plate 9: Swamp taro in straw-rope bags

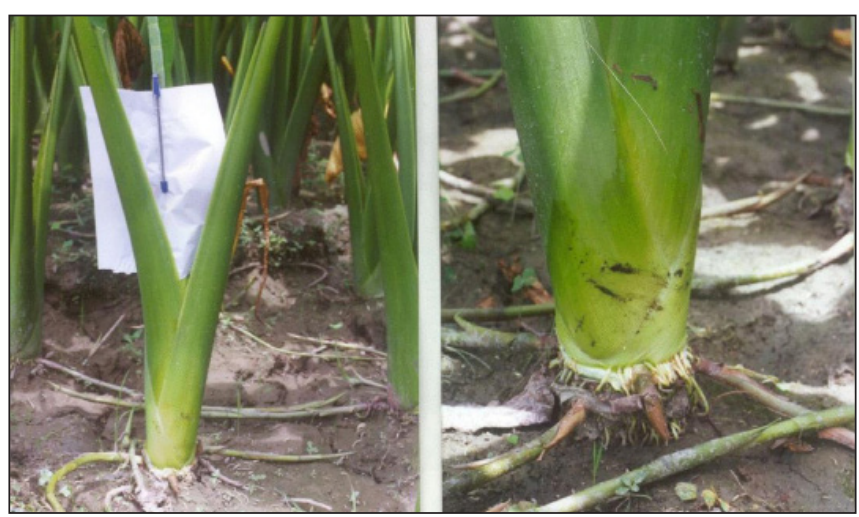

Plate 10: Runners of swamp taro

A good crop of swamp taro cv. BCST15 is planted in nursery during January at $60 \times 75 \mathrm{~cm}^{2}$ spacing with FYM @ 8.0 t ha ${ }^{-1}$ and $\mathrm{N}: \mathrm{P}_{2} \mathrm{O}_{5}$ and $\mathrm{K}_{2} \mathrm{O} @ 50: 60: 60 \mathrm{~kg} \mathrm{ha}^{-1}$ may yield runners of $15 \mathrm{t}$ ha-1 under normal condition and $6 \mathrm{t} \mathrm{ha}^{-1}$ under submergence. Market price of ₹ $40 \mathrm{~kg}^{-1}$ may generate a net profit of about 4 lakhs.

\subsection{Fox nut/ makhana (Euryale ferox)}

Fox nut, known as makhana in Bihar, Uttar Pradesh and Punjab; nikori in Assam and thangjing in Manipur. It is a perennial plant native to eastern Asia that usually grows in ponds, still water bodies and wet lands. The leaves are more than a meter in diameter. Bihar state of India accounts for 96,000 ha area under this crop due to its customary and ritual use in 'Chhatt' festival (plate 11 a. to 11e).

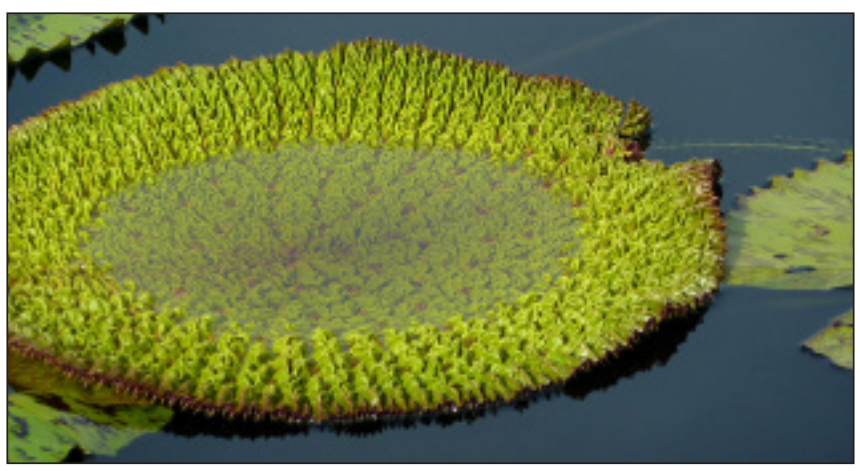

Plate 11.a: Makhana leaves floating

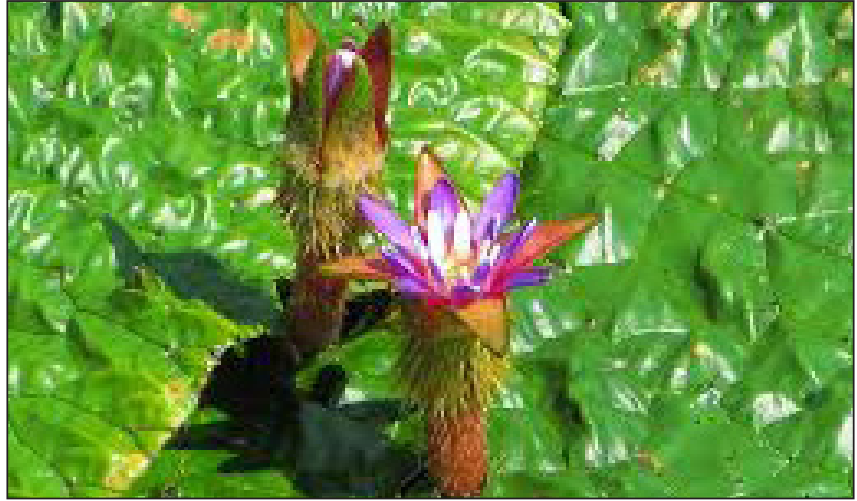

Plate 11.b: Makhana flowers

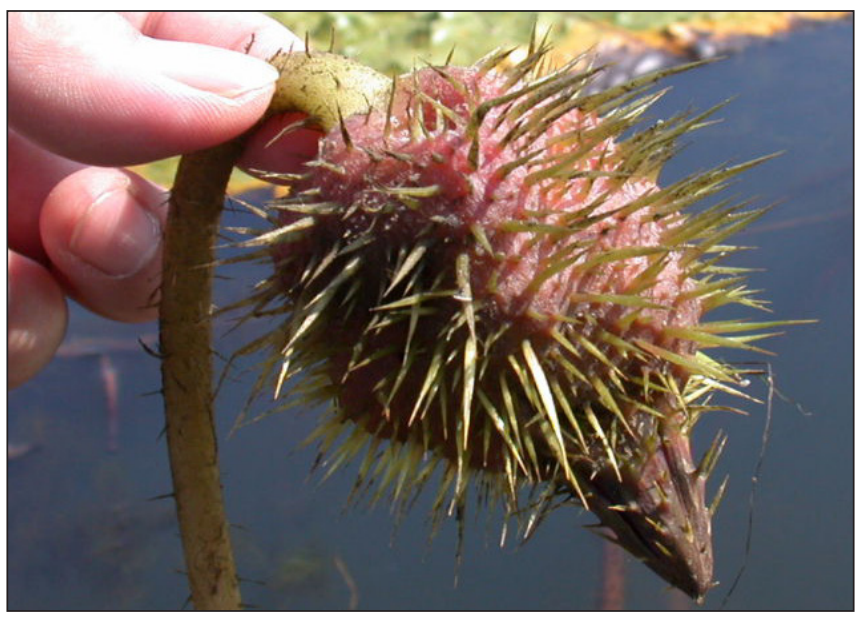

Plate 11.c: Makhana fruit
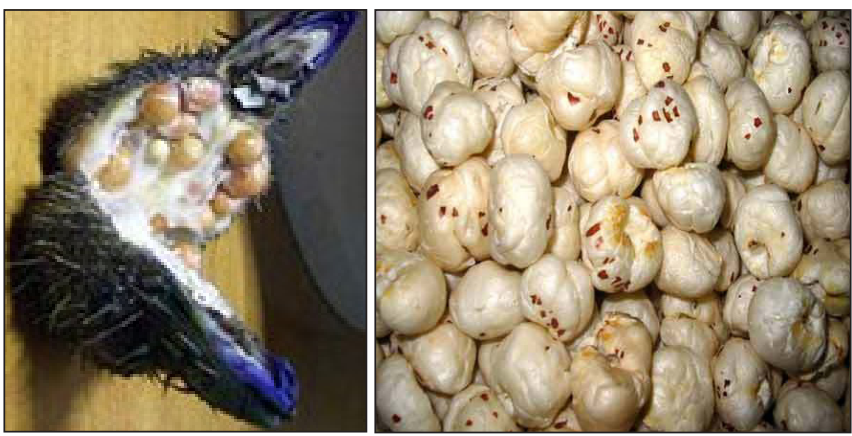

Plate 11.d: Seeds in fruit Plate 11.e: puffed consumable seeds

Sources: http://zipcodezoo.com/index.php/File:Euryale_ferox_18.jpg (Plate 11.a), http:// zipcodezoo.com/index.php/ Euryale_ferox (plate 11.b), http://www.indiamart.com/ proddetail/special-phool-makhana-2933403755.html (plate 11.c) and http://www. thefloweringgarden.com/euryale-ferox.htm (plate 11.d and 11.e).

Seeds after soaking for two days are sown in nursery at the end of January and planted in April to May at $100 \mathrm{~cm} \times 120$ $\mathrm{cm}$ with fertilizer dose $\left(\mathrm{N}: \mathrm{P}_{2} \mathrm{O}_{5}\right.$ and $\left.\mathrm{K}_{2} \mathrm{O}\right)$ of $30: 40: 40 \mathrm{~kg} \mathrm{ha}^{-1}$. It starts flowering after 2-3 months. Repeated harvesting of fruits @ 2-3 numbers plant ${ }^{-1}$ harvest $^{-1}$ continues for a period of next 5-6 months up to November. It produces an average 
25-30 fruits plant ${ }^{-1}$ in to to. The fruits are sold in market @ ₹ 1-3 depending on its seasonal demand may give a profit of one lakh. Due to its unique medicinal effects on acute diabetes, the seeds are in great demand even during off-seasons. A conservative techno-economic estimation of this crop with average 5,000 plants ha ${ }^{-1}$ and 20 fruits plant ${ }^{-1}$ sold @ Rs.1.5 fruit $^{-1}$ indicated a net profit of ₹ 90,000 ha-1.

\subsection{Hogla/sopo (Typhus elephantine/domingensis)}

Hogla, a front-door scenic crop/ weed plant known as sopo in north-eastern Odisha. It is found in most parts of the marshy and swampy lowland of West Bengal. There are several species of genus Typhus but $T$. elephantine and T. domingensis are important due to their economic values in making mats and roof-tops for temporary sheds of seasonal labourers around brick-kilns apart from medicinal uses in curing leprosy, spleen enlargement and measles (plate 12 to 14 ).

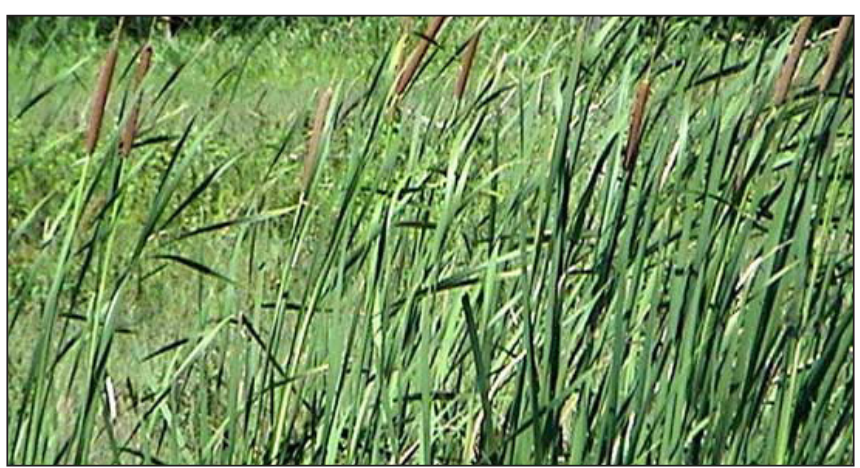

Plate 12: Hogla plants in natural ecosystem

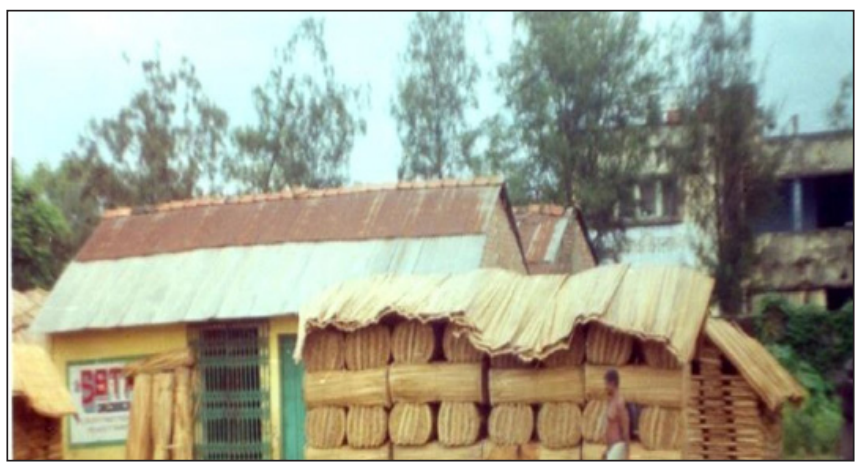

Plate 13: Trade cntre for sale of sopo

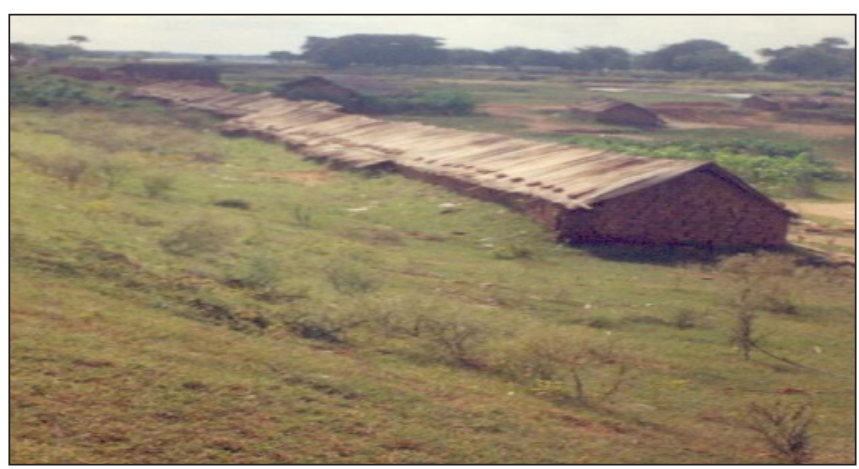

Plate 14: Temporary sheds near brick-kilns
The stubbles are planted in May to June and it is harvested after 5-6 months in two phases. First harvesting is done in early November to fetch better price and succeeding harvesting is done in late November or December. Application of FYM @ 15 t ha-1 along with N: $\mathrm{P}_{2} \mathrm{O}_{5}$ and $\mathrm{K}_{2} \mathrm{O} @ 30: 40: 40 \mathrm{~kg}$ $\mathrm{ha}^{-1}$ may yield $30.0 \mathrm{t} \mathrm{ha}^{-1}$ of economic output with a net profit of ₹ $72,300 \mathrm{ha}^{-1}$.

\subsection{Sweet flag/ bacha (Acorus calamus)}

Sweet flag is well known as bacha in Hindi and domesticated from wild habitat due to its growing medicinal values. It has recently been enlisted as "threatened species" in the IUCN red list. Growing tops or shoot recovered from the previous crop are plan at a spacing of $30 \times 30 \mathrm{~cm}^{2}$ during second fortnight of June in almost all types of soils. Population of $1,00,000$ to $1,10,000$ plants ha ${ }^{-1}$ could raise rhizome yield of $4.0 \mathrm{t} \mathrm{ha}^{-1}$ that may generate net profit of more than 5 lakhs ha-1.

\section{Special Cultivation Practices}

\subsection{On farm land alterations}

Provisions are made for taking up engineering measures in alteration of land surface. This may create ample scope for converting nearly useless perennial waterlogged land into potentially productive arable land systems. Meticulous selection of most befitting crop types and varieties in this modified terrain has yet revolutionized the entire gamut of farming at this age. Simple soil work required for effective survival of bio-draining tree species in shallow lowlands. Massive land alteration executed in raised and sunken bed method in other hand creates an opportunity to cater excess water situations at varying levels.

\subsection{Bio-drainage}

Availability of water is quite essential for the productivity of crop plants but the excess water situation in agricultural field is a serious challenge leading green house gas emission from waterlogged areas and marshy lands. Perennial tree species like Casuarinas, Acacia sps., Eucalyptus sps., etc. are usually recommended for bio-drainage in waterlogged agricultural fields (plate 15 and 16). The selection of tree species should be such that their root system readily extracts water from both surface and underground, and releases it into the atmosphere

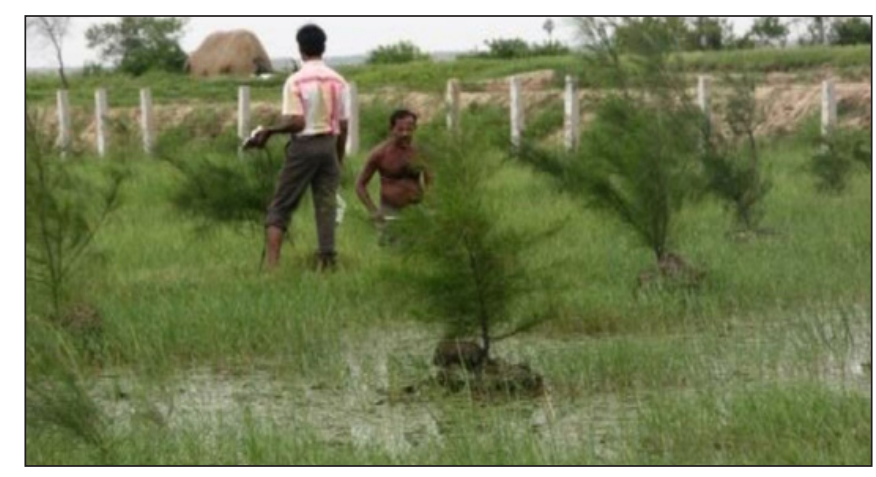

Plate 15: Direct seeding of ice in Casuarinas 


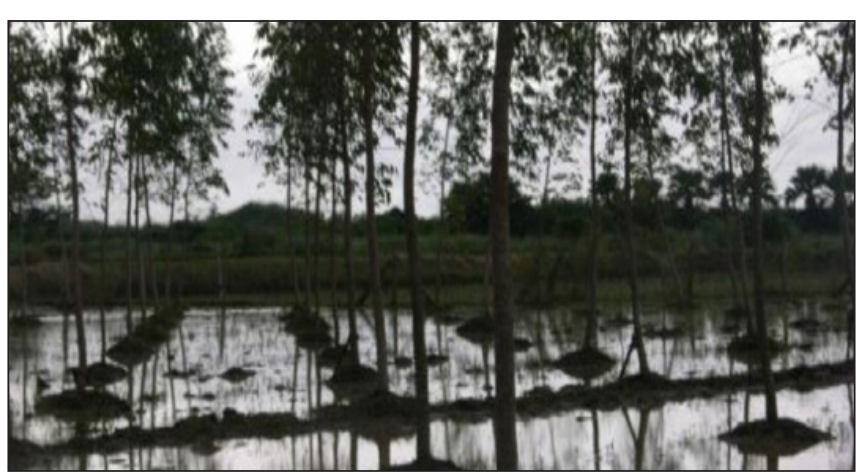

Plate 16: Turmeric intercrop in Casuarinas

through transpirational mechanism. In coastal tracts, ingress of sea water leads to soil salinity that requires additional special characteristics of such bio-drainers to survive and grow under saline conditions. Tree species like Tamari troupe, Prosodies jaliflora, Acacia farnesiana play great role up to salinity level of $35 \mathrm{dS} \mathrm{m}^{-1}$. Acacia nilotica, A. tortilis and Eucalyptus camaldulensis. undergo satisfactory growth up to $25 \mathrm{dS} \mathrm{m}^{-1}$. A little land transformation like mound-making for planting of the tender saplings of such species is advisable to avoid mortality.

\section{Raised and Sunken Bed Method}

Alternate raised and sunken bed method as developed by the Water Technology Centre for Eastern India, Bhubaneswar. It has advantage of catering the excess water conditions in low and medium land in canal commands that effectively created befitting habitats for high value profitable enterprises like vegetables on raised beds and rice-cum-pisciculture in sunken beds. The soil from the problematic area is dug at $5.0 \mathrm{~m}$ width in alternate strips at $30 \mathrm{~cm}$ depth. The same is spread over the adjacent strips to raise it up transforming into a well-drained leveled land surface befitting for most of the vegetables throughout the year. The water from the sunken bed can be supplemented for irrigating these crops as and when required and at the same time the sunken bed may be successfully covered with water loving crops like paddy or taro depending on the duration of moisture availability (plate 17 and 18)..

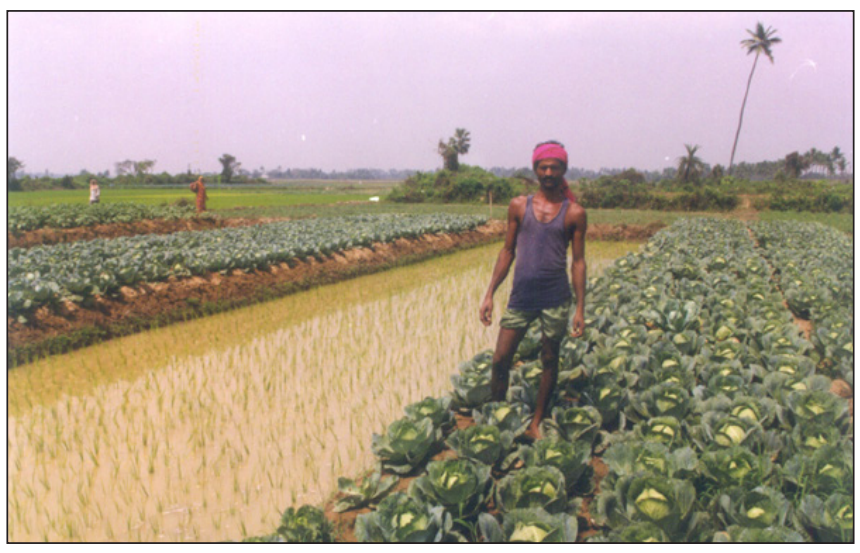

Plate 17: Raised-sunken beds with cauliflower and rice

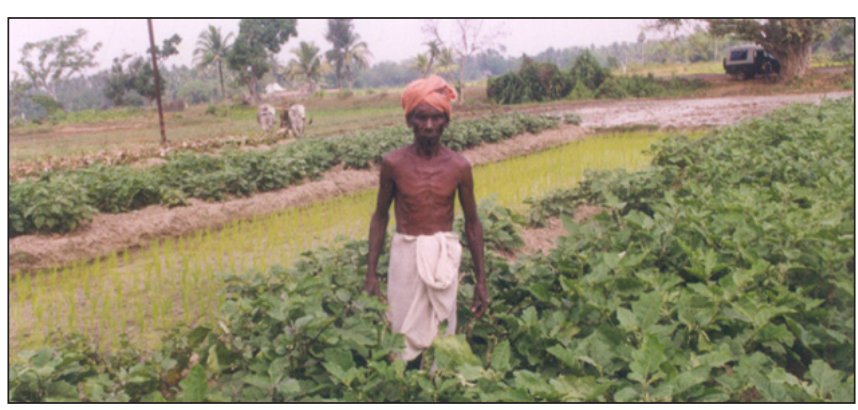

Plate 18: Brinjal and rice in raised-sunken beds; Source; IIWM, Bhubaneswar (Plate-13 to 18)

\section{Conclusion}

Judicious, cost effective and timely regulation of soil-plantwater continuum mingled with cropping of agro-ecologically befitting species like water chestnut, sweet flag, fox nut, hogla, para grass, etc. and suitable cultivars like Swarna Sub1, Sarala Sub1, Pratikshya, Varshadhan, Hangseswari, etc. have been found economically viable in such emerging moisture regimes. Adoption of bio-drainage techniques in waterlogged areas not only enhances land and water productivity but also substantially reduces the emission of green house gases thereby safeguarding the global environment from potential future climate change.

\section{Acknowledgement}

The first author acknowledges the encouragement received from the Late Dr. Gopal Chandra De, Professor, Agronomy, Sriniketan, Visva-Bharati, West Bengal, India as a mentor not only during his Doctoral research but also in investigating the rice ecologies of Odisha for betterment of the farming community at large that eventually came out with an Oriya booklet entitled "Jalakranta anchala krushi parichalana" and this manuscript as a co-author. 